\title{
DRAMOS TERAPIJOS METODU TAIKYMAS ERGOTERAPIJOS STUDIJŲ METU
}

\author{
Salomėja Burneikaitė, Valda Šertvytienė, Andrius Stasiulis \\ Klaipédos universiteto Sveikatos mokslu fakultetas
}

Raktažodžiai: ergoterapija, dramos terapija, proceso drama, interaktyvūs dramos metodai.

\section{Santrauka}

Straipsnyje pristatoma dramos terapijos metodų taikymo patirtis Klaipedos universitete ergoterapijos studijų metu. Jame atskleidžiama, kokiu būdu dramos terapijos metodai praktiškai studentams pateikiami kaip kūrybiškumo atskleidimo instrumentai ir viena iš meno terapijos sričių. Grupinių užsiemmimų metu studentai įsitrauke ị veiksmą, dalijosi patirtimi, kurdami kartu proceso dramą, kurios pagrindinis veikèjas - judejjimo ir kompleksinę negalią turintis asmuo. Straipsnis supažindina su proceso dramos kūrimo etapais, aptariamos studentų patirtys jų metu, analizuojamas naudotu dramos terapijos metodų taikymo efektyvumas. Anketinė apklausa, atlikta per empirinių tyrimų ir stebėsenos proceso analizę, atskleidžia, kaip dalyviai jaučiasi ir kaip suvokia dramos terapijos metodu poveikị. Nuosekliai išdèstyti darbo etapai grupès darbe ir proceso dramos plètojimas, pagal sutartas taisykles, padèjo dalyviams pažinti, drąsiau atsiverti ir išreikšti save, remiantis asmeniniu kūrybiškumu rasti geriausius sprendimus nestandartinèse aplinkybėse.

Proceso dramos „Fredis“ struktūra ir patirtys grupejje pateikiamos I lentelèje, ịvardijant atskiras jos dalis, tikslus, užduotis, veiksmus ir įžvalgas. Anketinès dalyvių apklausos rezultatai atskleidžia, kad studentų lūkesčiai buvo mažesni, negu igytas dramos terapijos metodu praktinis patyrimas. Analizuodami gautus duomenis matome, kaip ženkliai keitèsi jausminè ir kūrybinè grupès narių nuotaika sesijų metu. Visi apklausoje dalyvavę studentai pripažino, kad dalyvaudami dramos terapijos sesijose jie patyré gerų emocijų, pasijuto artimesni, sužinojo ir gavo netikètų patirčių apie save, grupès narius ir galbūt būsimus pacientus. Taigi, galima teigti, kad interaktyvių dramos metodų taikymas ergoterapijos studiju procese, plètojant proceso dramą, yra tinkamas metodas integruotai mokantis ne tik svarbiu profesiniu dalyku, bet ir tinkamo bendravimo, profesinès etikos, atsakingai rengiantis ergoterapeuto praktikai.

\section{Ivadas}

Dramos terapija yra viena iš meno terapijos sričių. Dramą Dabartinès lietuvių kalbos žodynas apibrèžia kaip kūrinį, parašytą dialogo ir monologo forma, pritaikytą vaidinti scenoje arba rimto turinio vaidinamaji kūrinị [2]. Iš teatro istorijos žinome, kad drama, kaip „rimtas vaidinamasis kūrinys", siekia antikos laikus. Atsirasti dramos terapijai postūmį davė XX a. pradžioje J. L. Moreno suformuluota psichodramos idejja. Tai yra grupinio darbo metodai, gimę panaudojant teatro galimybes, tačiau tai, kas grupejje kuriama, nèra skirta žiūrovams. Dramos terapija kryptingai renkasi teatro technikų naudojimą asmeniniam augimui, tobulejimui. Tai interaktyvių veiksmo metodų visuma, padedanti grupès dalyviams vaidmenų žaidimų, improvizacijų, refleksijų metu gauti naujų patirčių, įvardyti emocijas, leidžiančias geriau pažinti save, grupès narius bei gyvenimo dèsnius. Tikslingai dirbant dramos metodai tampa paveikiu terapijos bei asmenybès savireguliacijos instrumentu. Per veiksmą, bendravimą, garsą ir žodị, naudojant lèles ar kaukes, judesio plastiką, dramos terapijos metodai padeda dalyviams giliau pažinti save ir kitą, mokytis atpažinti paciento poreikius, padèti išlaikyti pusiausvyrą tarp savęs ir aplinkos, skatina tobulèti. Ši meno terapijos rūšis, kaip viena iš kūrybiškumo ugdymo instrumentų, itin svarbi ergoterapeutams, siekiantiems padèti žmonèms atgauti prarastas jègas, atstatyti pažeistas funkcijas arba igyti naujų kompetencijų.

Reabilitacijos katedros programoje, pagal kuria Klaipédos universiteto Sveikatos mokslų fakultete studijuoja būsimieji ergoterapijos bakalaurai, studentai supažindinami su įvairiais kūrybiniais metodais, išbando juos praktiškai. Ruošdamiesi susitikti su pacientais jie turi galimybę patys patirti, kokios svarbios sveikatai yra žmogaus emocijos, 
jausmai ir mintys. „Žmonès, kurie nustoja kurti, ,„stringa“ negatyvioje savo būsenoje ar ligoje. Jiems sunku ịsivaizduoti, kad pasaulis gali būti ir kitoks - žymiai įdomesnis ir spalvingesnis. Neigalūs žmonès, ypač sergantys sunkesnių formų ligomis - šizofrenija, depresija, autizmu, nustoja vaizduotès galios" - teigia dailès terapeutè L. Kriukienè [3]. Mokslininkai yra nustatę tiesioginį meno terapijos ir vaizduotès ryšị. Todèl sudaromos sąlygos, kad būsimieji ergoterapeutai, igydami profesines kompetencijas ir ruošdamiesi dirbti sveikatos atstatymo srityje, ugdytų ir vaizduotès savybes, pažintų savo kūrybines galias, kad galètų tinkamai padèti pacientams. Dramos terapijos metodai padeda būsimiesiems specialistams pasirengti dirbti ir reabilitacijos komandoje. İsitraukimo ị veiksmą būdu ugdomi jų gebejjimai užmegzti kontaktą su pacientais, atpažinti šių poreikius stebint kūno kalbą, laisvai bendraujant mokytis bendradarbiauti.

Didelę dramos terapijos kurso dalį sudaro dramos elementų pažinimas, parengiamieji pratimai, žaidimai rolėmis, darbas grupèse, suteikiant galimybę improvizuotai veikti įsivaizduojamose aplinkybėse, laisvai reikšti mintis, mokantis koncentruoti bei išlaikyti dèmesį, motyvuotai siekti tikslo.

Darbo tikslas: pristatyti dramos terapijos metodų patyrimą ergoterapijos studijų metu, aptariant grupinio ịsitraukimo veiksmus proceso dramos sesijų metu bei išanalizuoti asmeninę studentų nuomonę apie dramos terapijos patirtis.

\section{Medžiaga ir tyrimo organizavimas}

Dramos terapijos paskaitų metu penkiolika ergoterapijos programos II kurso studenčių dalyvavo empiriniame tyrime, kuris buvo vykdomas kartu kuriant proceso dramą. Užsiëmimai vyko kartą per savaitę, po dvi akademines valandas. Iš viso buvo aštuoni užsièmimai, atliekant ir savarankiškas užduotis namuose. Baigus darbą grupejje anketavimo būdu išsiaiškinta dalyvių nuomonè apie dramos terapijos patyrimą. Gauta 10 užpildytų anketų. Dalyvių amžius buvo nuo 20-ies iki 36-rių metų. Apklausa vykdyta po dramos terapijos paskaitu kurso, išdèstyto $2013 \mathrm{~m}$. kovo-gegužès mėnesiais, nenurodant asmeninių duomenų.

Proceso dramos kūrimas dramos terapijos paskaitose. Proceso drama - vienas iš interaktyvių dramos metodų, išbandytų Didžioje Britanijoje ir plačiai taikomų Europoje, ypač Anglijoje bei Skandinavijos šalyse. Universitetiniu lygmeniu drama dèstoma aukštosiose mokyklose, kaip dalykas, padedantis kokybiškai mokytis, panaudojant daugybę mokymosi būdų, metodų ir veiklų, kurios atskleidžia grupès narių tam tikrus emocinius, fizinius, intelektualinius gebejjimus ir padeda juos ugdyti. Grupés nariai, dalyvaudami proceso dramoje, tampa kartu ir žiūrovais, ir dalyviais. Remtasi garsaus britu proceso dramos eksperto, UK Royal
Society of Arts nario, profesoriaus dr. Alanas Ovensas (Allan Owens), kūrusio ir propaguojančio dramos metodus, skirtus asmeninėms įžvalgoms ir mokymuisi per trisdešimt metų, teiginiu, kad ,proceso dramose pateikiamos istorijos skatina individualiai mąstyti ir savas mintis lyginti su grupès ar paplitusia visuomenès nuomone“ [4]. Sąvoka proceso drama pradèta vartoti XX a. 9-jo dešimtmečio pabaigoje. Anot Allan Owens, ,proceso drama yra vienas iš teatro įtraukiant žiūrovus būdų, kur pagrindinis vaidmuo tenka dalyviams. Dalyvių tikslas - vaidinant atrasti ryšs tarp tam tikro reiškinio ir svarbaus jų gyvenimo įvykio“" [5].

Dramos terapijos paskaitu metu buvo susitarta kurti proceso dramą, pavadinimu „Fredis“. Jos tema pasirinkta siekiant padèti ergoterapijos studentams suvokti žmonių su negalia gyvenimo bendruomeneje jausmus, problemas, aplinkybes. Pretekstu kurti „Fredžio“ istoriją pasirinkta didelè tekstilinė aštuonkojo lèlè, pasodinta neigaliojo vežimèlyje, sukurta ir pagaminta prieš penkerius metus VI Neiggaliujų cente „Klaipedos lakštute““ ir dovanota Reabilitacijos katedrai. Fredžio vardu dar 2009 m. lèlę žaidybiškai pavadino vienas pirmosios laidos ergoterapijos studentų. Lèlė Fredis nejučia tapo savotišku mediumu komunikacijos [1] ir įsivaizduojamu „laisvuoju klausytoju“ ergoterapijos programos studentams, tinkamu ,tarpininku“, simboliškai padedančiu jiems bendrauti profesinèmis temomis.

Kaip ịprasta, tiriamuoju laikotarpiu kiekviena dramos terapijos paskaita buvo pradedama apšilimu, t.y. draminiais pratimais-žaidimais, atkreipiant dèmesị į šios dienos temą. Toliau ji buvo vystoma nuosekliai grupei ịsitraukiant i veiksmą. Siekiant kurti tikrovišką istoriją buvo naudojami tokie metaforiški dramos struktūros elementai kaip ,,personažo kūrimas“, „erdvės aprašymas“, „gyvieji paveikslai“, „stop kadras“, „karštoji kẻdë“, „laiškas“ ir kt. Po improvizuoto veiksmo etiudų nuolat grupé aptardavo kilusius klausimus, jausmus, mintis, patirtis. Vyko diskusijos, dalinantis asmeninėmis įžvalgomis. Bendru sutarimu buvo imamasi savarankiškų užduočių namuose. Žemiau pateikiama grupejje kurtos proceso dramos „Fredis“ vystymo eiga ir jos epizodai: apšilimas - dramos žaidimu metu pristatoma istorija, supažindinama su situacija; portretas - apibūdinama lèlès-personažo „Fredis“ išvaizda, savybès, pomėgiai, biografijos epizodai, ji įtraukiant i i studentų ratą; aplinka - pasitelkus vaizduotę diskusijų metu kuriamos lèlès-personažo gyvenimo sąlygos, aplinkybès, artimi žmonès ir pan.; laimingas ịvykis - aptarus mažose grupelèse improvizuotai suvaidinamas ir užfiksuojamas kaip ,stop kadras“, brangiausias pagrindinio herojaus gyvenimo ivvykis; paslaptis - grupelèse aptariamas vidinis herojaus gyvenimas ir surandamas svarbus neviešas jo gyvenimo faktas; svajonė - veikiant mažomis grupelèmis ir aptariant jose gau- 
tas patirtis, suformuluojama herojaus siekiamybè, vizija, $\underset{\mathfrak{i}}{\mathrm{a}}$ kurią galima koncentruoti grupès dèmesị, kreipti kūrybinę energiją, ieškant būdų kaip siekti jos įgyvendinimo, spręsti problemą ar teikti pagalbą; reziumė - išklausius grupès narių minčių, studentams, vietoj herojaus, t.y. lèlès Fredžio, patiems sèdint rateliuose ir atsakant i dalyvių klausimus, formuluojamos išvados, ižvalgos, rekomendacijos; kaip tai siejasi su jūsų gyvenimu - refleksija grupeje, aptariant kuriamos proceso dramos „Fredis“ situaciją asmeninių išgyvenimų bei profesinių patyrimų kontekste.

Proceso dramos „Fredis“ struktūra ir patirtys grupeje pateikiamos 1 lentelèje.

Studentų nuomonė apie dramos terapiją. Baigus dramos terapijos kursą dauguma dalyvių sutiko atsakyti į anketos klausimus, kuriais siekta išsiaiškinti studentų nuomonę apie dramos terapiją ir dalyko reikšmę studijų procese. Gauta dešimt užpildytų anketų. Išanalizavus atsakymus sužinota dalyvių nuomonè apie dramos terapiją. Studentėms buvo pateikti penki atviri klausimai. Atsakymų i juos rezultatai atskleidžia kokybines ir kiekybines nuomoniu charakteristikas:

1. Kokios asociacijos kilo iki studijų apie „,dramos terapijos" dalyką?

Dramos terapija asocijuojasi su teatru, vaidyba, saviraiška - 9 studentèms, su emocijomis, nuoširdumu, atvirumu - 1 .

2. Ko tikejjotès iš dramos terapijos ciklo?

Tikejjosi geriau pažinti save ir savo bendrakurses 3 studentès, išmokti atsipalaidavimo bei pasitikejjimo savimi 3 , naujų žinių, metodikų būsimam darbui su pacientais -4 .

3. Kaip kito jūsų nuomoné apie dramos terapiją paskaitų metu?

Visos 10 studenčiu

\section{1 lentelė}

pripažino, kad dalyvaudamos dramos terapijos užsièmimuose patyre gerų emocijų, sužinojo apie save naujų dalykų ir pripažįsta, kad proceso dramos kūrimas - tinkamas būdas integruotai mokytis svarbių dalykų ergoterapeuto darbe. Visos pažymejo, jog juto kintančią grupès nuotaiką paskaitų metu. Aštuonioms iš jų pradžioje trūko pasitikejjimo savimi, prisipažino, kad jaute baimę bendrauti, atsiverti, atlikti kai kurias užduotis. Likusios dvi sunkumu nepatyrè. Devynioms grupès narèms didžiausią įspūdị paliko proceso dramos „Fredis“ kūrimas, vienai ryškiausiai atmintyje išliko tam tikros paskaitose pateiktos metodikos - sąmoningi dèmesio fokusavimo būdai, jo koncentracija, tylos funkcija.

4. Kuo naudinga buvo dramos terapija studentei $-b \overline{-}-$ simai ergoterapijos specialistei?

\begin{tabular}{|c|c|c|c|c|}
\hline \multirow[b]{2}{*}{$\begin{array}{c}\text { Proceso } \\
\text { dramos dalys }\end{array}$} & \multirow[b]{2}{*}{ Tikslas } & \multirow[b]{2}{*}{$\begin{array}{l}\text { Užduotis arba } \\
\text { veiksmas }\end{array}$} & \multicolumn{2}{|c|}{ İžvalgos } \\
\hline & & & $\begin{array}{l}\text { apie pagrindinị } \\
\text { veikèją Fredị }\end{array}$ & $\begin{array}{c}\text { apie asmenines } \\
\text { patirtis }\end{array}$ \\
\hline $\begin{array}{l}\text { Lèlès } \\
\text { Fredžio, } \\
\text { rateliuose } \\
\text { istorija } \\
\end{array}$ & $\begin{array}{l}\text { Nusiteikti kurti } \\
\text { grupeje proceso } \\
\text { dramą "Fredis", } \\
\text { stengiantis jam padetti }\end{array}$ & $\begin{array}{l}\text { Išklausyti ir suvokti } \\
\text { neigalaus žmogaus } \\
\text { gyvenimo aplinkybes } \\
\text { ir dabarties situaciją }\end{array}$ & $\begin{array}{l}\text { Fredis - vienas } \\
\text { iš mūsų }\end{array}$ & $\begin{array}{l}\text { Susitariama } \\
\text { dėl ,žaidimo } \\
\text { taisyklių“، }\end{array}$ \\
\hline $\begin{array}{l}\text { Individualus } \\
\text { Fredžio } \\
\text { portretas }\end{array}$ & $\begin{array}{l}\text { Kūrybiškai pristatyti } \\
\text { lëlès-tariamo kurso } \\
\text { draugo problemą ir } \\
\text { situaciją }\end{array}$ & $\begin{array}{l}\text { İsivaizduoti ir } \\
\text { apibūdinti laisvojo } \\
\text { klausytojo Fredžio } \\
\text { asmenines savybes, } \\
\text { būdą, apribojimus }\end{array}$ & $\begin{array}{l}\text { Fredis - svajoja } \\
\text { ir turi tikslų }\end{array}$ & $\begin{array}{l}\text { Fredis - mūsų } \\
\text { pacientas, kuriam } \\
\text { galima padèti }\end{array}$ \\
\hline $\begin{array}{l}\text { Fredžio vieta } \\
\text { grupèje }\end{array}$ & $\begin{array}{l}\text { Patirti kaip jaučiasi } \\
\text { žmogus neigaliojo } \\
\text { vežimèlyje (judejjimo, } \\
\text { savivokos, pažinimo } \\
\text { ir kt. galimybės) }\end{array}$ & $\begin{array}{l}\text { Judèti ir atsakinèti } \\
\text { ị klausimus Fredžio } \\
\text { rolèje studentėms } \\
\text { pačioms sèdint } \\
\text { rateliuose }\end{array}$ & $\begin{array}{l}\text { Fredis nori } \\
\text { pamatyti } \\
\text { pasauli, siekia } \\
\text { mokytis, žavisi } \\
\text { dailès terapija }\end{array}$ & $\begin{array}{l}\text { improvizuojant } \\
\text { Fredžio rolèje } \\
\text { patiriama ką } \\
\text { herojus išgyvena, } \\
\text { mąsto, gali }\end{array}$ \\
\hline $\begin{array}{l}\text { Fredžio } \\
\text { problemos }\end{array}$ & $\begin{array}{l}\text { Sukurti aplinkybes } \\
\text { empatiškai pajausti } \\
\text { bei palyginti savo ir } \\
\text { herojaus galimybes }\end{array}$ & $\begin{array}{l}\text { Ištirti su kokiais } \\
\text { apribojimais susiduria } \\
\text { neigalus žmogus } \\
\text { asmeniškai ir } \\
\text { visuomeneje }\end{array}$ & $\begin{array}{l}\text { Fredžiui sunku } \\
\text { būti suprastam } \\
\text { ir pasiekti tai ko } \\
\text { nori }\end{array}$ & $\begin{array}{l}\text { Aš, grupè ir } \\
\text { Fredis galime } \\
\text { kartu keisti } \\
\text { situaciją }\end{array}$ \\
\hline $\begin{array}{l}\text { Fredis - } \\
\text { vienas iš } \\
\text { mūsų }\end{array}$ & $\begin{array}{l}\text { Suteikti galimybę } \\
\text { atpažinti jausmus, } \\
\text { pripažinti juos ir } \\
\text { ịvardinti }\end{array}$ & $\begin{array}{l}\text { Improvizuoti veiksmo } \\
\text { etiudai - ,jeigu aš } \\
\text { galéčiau“ ... }\end{array}$ & $\begin{array}{l}\text { Nesunku } \\
\text { Fredžiui suteikti } \\
\text { džiaugsmo ir } \\
\text { padèti jaustis } \\
\text { gerai }\end{array}$ & $\begin{array}{l}\text { Gera ir malonu } \\
\text { jausti, kad galiu } \\
\text { padèti kitam }\end{array}$ \\
\hline $\begin{array}{l}\text { Fredžio } \\
\text { gyvenimas } \\
\text { keičiasi }\end{array}$ & $\begin{array}{l}\text { Padèti atsiskleisti } \\
\text { asmeniniam } \\
\text { kiekvieno grupės } \\
\text { nario kūrybiškumui }\end{array}$ & $\begin{array}{l}\text { Užduotys namuose, } \\
\text { pasiimant „Fredị““ } \\
\text { savaitei ị kitą aplinką, } \\
\text { o grupėje - veiksmo } \\
\text { refleksija }\end{array}$ & $\begin{array}{l}\text { Nauji žmonès, } \\
\text { nauji iššūkiai, } \\
\text { įspūdžiai, } \\
\text { svajonès }\end{array}$ & $\begin{array}{l}\text { Fredžio dèka } \\
\text { atsiskleidè naujos } \\
\text { draugų ir artimųų } \\
\text { savybès }\end{array}$ \\
\hline $\begin{array}{l}\text { Keičiasi } \\
\text { mūsų visų } \\
\text { gyvenimas }\end{array}$ & $\begin{array}{l}\text { Atskleisti kūrybiško } \\
\text { mąstymo vertę } \\
\text { siekiant gyvenimo } \\
\text { tikslų }\end{array}$ & $\begin{array}{l}\text { „Laiškas iš ateities“ } \\
\text { - iš laiko distancijos } \\
\text { ịvertinti nueito kelio } \\
\text { îvykius ir pasiekimus }\end{array}$ & $\begin{array}{l}\text { Fredis } \\
\text { padedamas } \\
\text { panašiems i } \\
\text { save padeda sau }\end{array}$ & $\begin{array}{l}\text { Dalyviai tapo } \\
\text { artimesni, labiau } \\
\text { pasitikintys } \\
\text { savimi, profesija }\end{array}$ \\
\hline
\end{tabular}


Dvi iš grupès prisipažino, kad išmoko naujovių (naujų technikų) ergoterapeuto darbe, o viena pažymejjo, kad išsiugdè daugiau kantrybès. Net šešios teigè išmokusios geriau komunikuoti bei pažinti žmones iš neverbalinès, t.y. kūno kalbos. Viena studente įvardijo patyrusi, kas yra grupinè terapija bei komandinio darbo patirtis.

5. Kokią įtaką dramos terapijos dalykas turejjo jums kaip žmogui?

Visos atsakiusios ị anketos klausimus studentès pastebejjo, kad po dramos terapijos paskaitų geriau pažista save, geriau atskiria savo jausmus. Nurode, kad dramos terapija padeda vystyti empatiją, kantrybę, pasitikèjimą savimi, laisvą saviraišką.

\section{Išvados}

Dramos terapijos dalykas ergoterapijos studiju metu, kai studentai ịtraukiami ị veiksmą naudojant interaktyvius kūrybinius metodus, padeda ịvaldyti ir derinti būtinas profesines kompetencijas. Dalyvaudami diskusijose, improvizuotai veikdami mažose grupelèse pratybų metu, studentai mokosi reikšti mintis, praktiškai užmegzti ir palaikyti pokalbị, giliau pažinti save, gebėti suprasti kitą žmogų (pacientą, klientą). Jie turi galimybę praktiškai išbandyti savo jègas modeliuodami idèjas saugioje žaidybinejje aplinkoje, kartu gilindami savivoką ir ruošdamiesi profesinei praktikai. Empirinio tyrimo metu iš anketinès apklausos ir analizuojant stebejjimo procesą išaiškejjo, kad studentai jaučia ir supranta dramos terapijos metodų poveiki. Proceso dramos kūrimas grupejje padejjo mokytis ieškoti geriausių sprendimų nestandartinėmis aplinkybėmis, atsiskleidžiant ir naujas savo asmenybės kūrybiškas puses, patirti bendros komandinès kūrybos džiaugsmą. Atsakymai ị anketos klausimus parodè, kad lūkesčiai ir nuomonès apie dramos terapiją keitėsi, jautėsi ir padejjo kūrybiška atmosfera užsièmimų metu. Absoliučiai visos studentės pripažino, kad dalyvaudamos dramos terapijos užsièmimuose patyre geru emocijų, pasijuto artimesnès, èmè labiau pasitikèti savimi, sužinojo apie save daug naujo. Galima teigti, kad proceso dramos kūrimas - tinkamas būdas integruotai mokytis svarbių dalykų, ruošiantis ergoterapeuto praktikai.

\section{Literatūra}

1. Burneikaitè S. Lèlių teatro technikų taikymas reabilitacijos procese. Klaipeda, 2012; 13.

2. Dabartinès lietuvių kalbos žodynas 2000; 129.

3. Kriukienè L. Dailès terapija/mokomoji knyga. Kaunas, Vitae Litera, 2009; 39.

4. Owens A., Barber K. Proceso drama: dramos darbai. /Kronta/ Vilnius, 2006; 16.

5. Tarptautinio seminaro „Socialinès dramos galimybès ir praktika“" medžiaga./ Metodinis leidinys / Vilnius, 2005; 8.

\section{DRAMA THERAPY METHODS IN OCCUPATIONAL THERAPY STUDIES}

\section{S. Burneikaitė, V. Šertvytienė, A. Stasiulis}

Key words: occupation therapy, drama therapy, process drama, interactive drama methods.

Summary

The article reveals the experience of application of drama therapy during occupational therapy studies. Drama therapy is presented as one of the fields of art therapy. The experiences of group involvement during drama therapy lectures, while developing a process drama, are discussed, and a personal view of students towards the impact of drama therapy is analysed. The questionnaire survey, conducted during empirical research, and the assessment of monitoring process demonstrated that students feel and perceive the impact of drama therapy methods. Group development of process drama helped to reveal themselves and to use personal creativity, when looking for the best solutions under non-standard circumstances. Responses to questionnaire questions show that the expectations and views towards drama therapy changed, while feeling the creative mood of group during sessions. All surveyed students acknowledged that they had experienced good emotions, had felt closer, had known something new about themselves, while taking part in drama therapy sessions. Thus, it might be stated that interactive drama methods and development of process drama is a suitable method for integrated learning of important subjects, when preparing for practice of occupational therapist.

Correspondence to: salomeja.burneikaite@gmail.com

Gauta 2015-05-21 